\title{
Annual Peak Streamflow and Ancillary Data for Small Watersheds in Central and Western Texas
}

\section{Background}

Estimates of annual peakstreamflow frequency are needed for flood-plain management, assessment of flood risk, and design of structures, such as roads, bridges, culverts, dams, and levees. Regional regression equations have been developed and are used extensively to estimate annual peak-streamflow frequency for ungaged sites in natural (unregulated and rural or nonurbanized) watersheds in Texas (Asquith and Slade, 1997; Asquith and Thompson, 2008; Asquith and Roussel, 2009). The most recent regional regression equations were developed by using data from 638 Texas streamflow-gaging stations throughout the State with eight or more years of data by using drainage area, channel slope, and mean annual precipitation as predictor variables (Asquith and Roussel, 2009). However, because of a lack of sufficient historical streamflow data from small, rural watersheds in certain parts of the State (central and western), substantial uncertainity exists when using the regional regression equations for the purpose of estimating annual peakstreamflow frequency.

In 2006, a streamflow-gaging program was begun to collect annual peak-streamflow data from small rural watersheds in central and western Texas. These annual peak-streamflow data will be used to develop statistical equations to estimate flood annual exceedance probabilities for other small ungaged rural watersheds for which the Texas Department of Transportation (TxDOT) designs culverts and other waterconveyance structures. A secondary objective of the program is to collect precipitation and continuous stage data for the estimation of storm hydrographs and hyetographs that could be used to investigate unit-hydrograph and rainfall-runoff characteristics.

\section{Estimating Peak Streamflow in Central and Western Texas}

The U.S. Geological Survey (USGS) currently operates 51 streamflow-gaging stations in central and western Texas, in cooperation with the TxDOT, as part of a data-collection program to primarily record annual peak stage (elevation of water surface above a datum) and estimate the annual peak streamflow in small rural watersheds (fig. 1). The contributing areas of the stations range in size from 0.002 to 194 square miles with an average of 10.8 square miles. Only four of the stations (07295450, 08080650, 08080918, and 08123620) have a contributing area of more than 20 square miles. All of the 51 stations are equipped with at least two crest-stage gages 


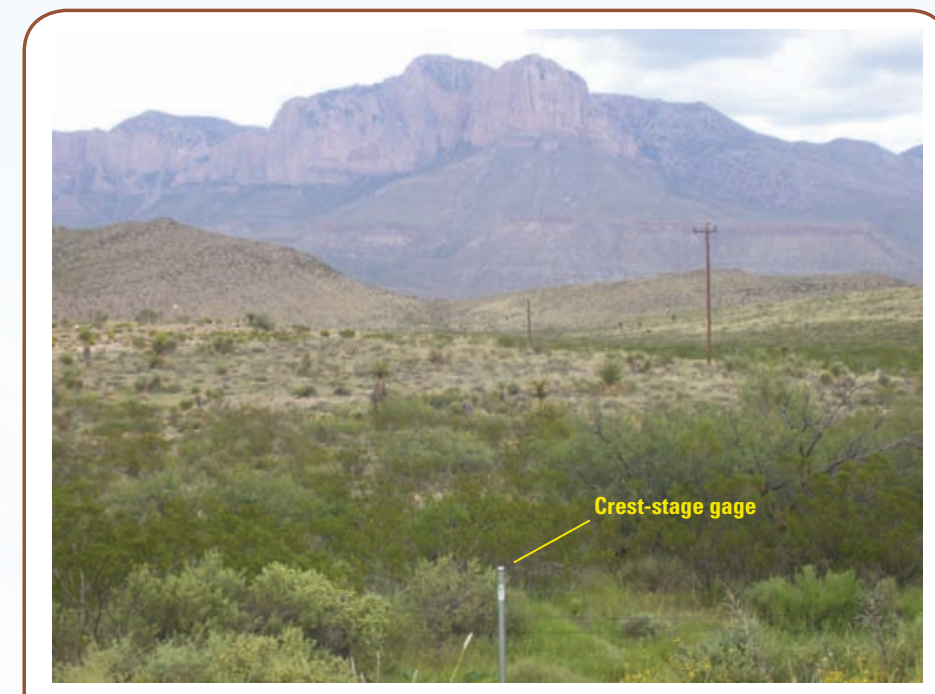

Figure 2. Example of a U.S. Geological Survey streamflow-gaging station (station 08407595, Guadalupe Arroyo, unnamed tributary 1 near Salt Flat, Texas) with crest-stage gages. Peaks in the background are El Capitan and Guadalupe Peak. Additional creststage gages at this station are not shown.

designed to record the maximum headwater and tailwater stage for the largest rise in water surface between service trips to the stations (figs. 2-4). A crest-stage gage is a simple way to passively record the maximum stage after an event. A wooden stick (typically 0.75 inches thick by 1.50 inches wide in various lengths) is placed within a 2-inch galvanized steel pipe that is mounted vertically in the path of flow either in the channel or attached to the face of the culvert headwall. At the bottom of the wooden stick, a mesh basket is secured and filled with a supply of granulated cork. The steel pipe has end caps on the top and bottom that are vented with pre-drilled holes to allow air to escape (vent). The bottom of the stick rests on a pin in the bottom cap of the pipe, and the elevation of the pin is surveyed and referenced to a common datum. As the stage rises, the cork floats up inside the pipe, and when the stage falls, a cork line is left on the wooden stick indicating the peak stage during the event. The stick is removed during a visit and the water level is recorded. To be ready for the next stormflow event, the cork line is removed from the stick, and the mesh basket is recharged with new cork.

Ten of the 51 stations are equipped with a precipitation gage and pressure transducers in both the upstream and downstream crest-stage gage pipes that record continuous stage data during events. Precipitation data and continuous stage data recorded by the transducers are downloaded during site visits; at the USGS office, these data are entered into the USGS National Water Information System database (U.S. Geological Survey, 2011) and thoroughly reviewed for quality assurance.

Three of the stations in the network (07227460, 08123620, and 08367050) are operated on a real-time basis. Stage and precipitation data are available online for the three stations (U.S. Geological Survey, 2011; table 1). Stage data are collected every 5 minutes and precipitation data every 15 minutes. These three stations were selected for real-time display because of their remoteness relative to USGS offices. Real-time stations in the network allow USGS staff to determine whether other stations might have received rain sufficient to cause a rise in stage. Some of the equipment used for real-time data collection with a crest-stage gage are shown in figure 5.

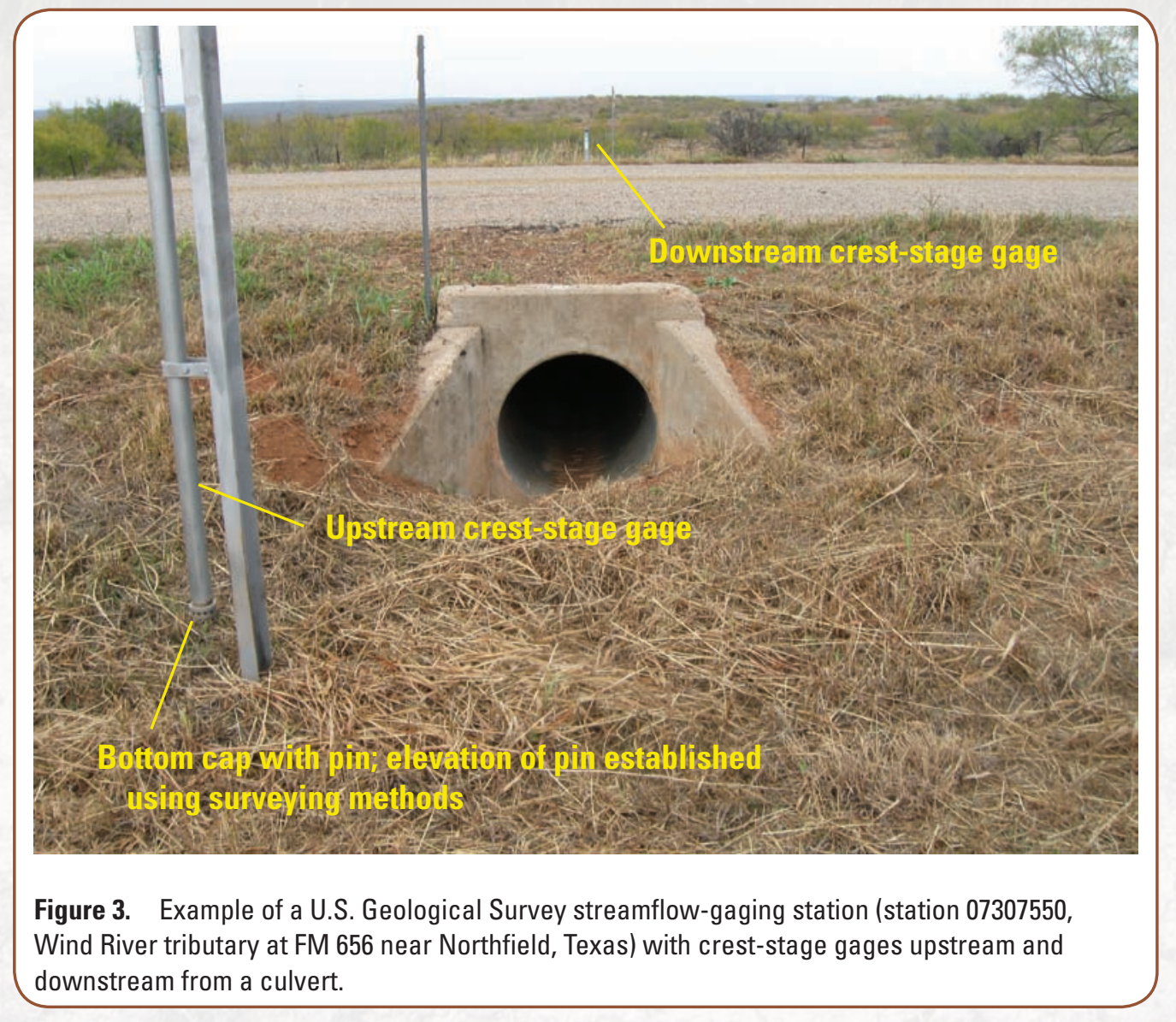




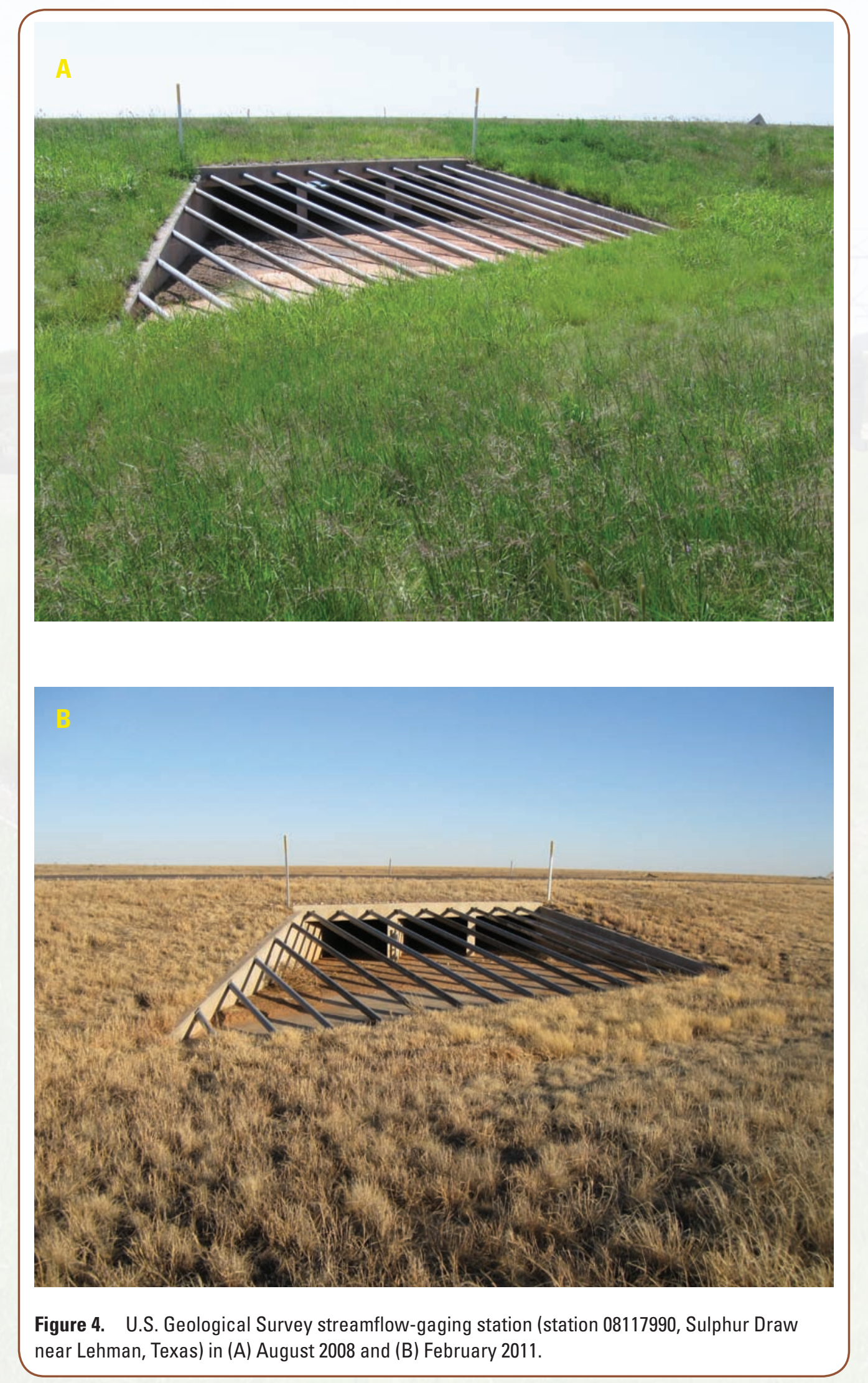

\section{Estimating Discharge from Culvert Hydraulics}

The flow of water through culverts has been studied extensively by the USGS and many other entities. Detailed methods for estimating discharge through culverts are documented by Bodhaine (1968). The methods are based on results of laboratory and field investigations (Carter, 1957). The USGS Culvert Analysis Program (CAP) enables the analyst to relatively quickly estimate peak discharge from headwater and tailwater stages, according to the procedures in the report authored by Bodhaine (Fulford, 1998). 
Table 1. Real-time U.S. Geological Survey streamflow-gaging stations operated in cooperation with the Texas Department of Transportation in central and western Texas, 2011.

\begin{tabular}{ccc}
\hline Station number & Available data & Web address \\
\hline 07227460 & Stage and precipitation & $h t t p: / / w a t e r d a t a . u s g s . g o v / t x / n w i s / u v / ? s i t e \_n o=07227460$ \\
08123620 & Stage and precipitation & $h t t p: / / w a t e r d a t a . u s g s . g o v / t x / n w i s / u v / ? s i t e \_n o=08123620$ \\
08367050 & Stage and precipitation & http://waterdata.usgs.gov/tx/nwis/uv/?site_no=08367050 \\
\hline
\end{tabular}

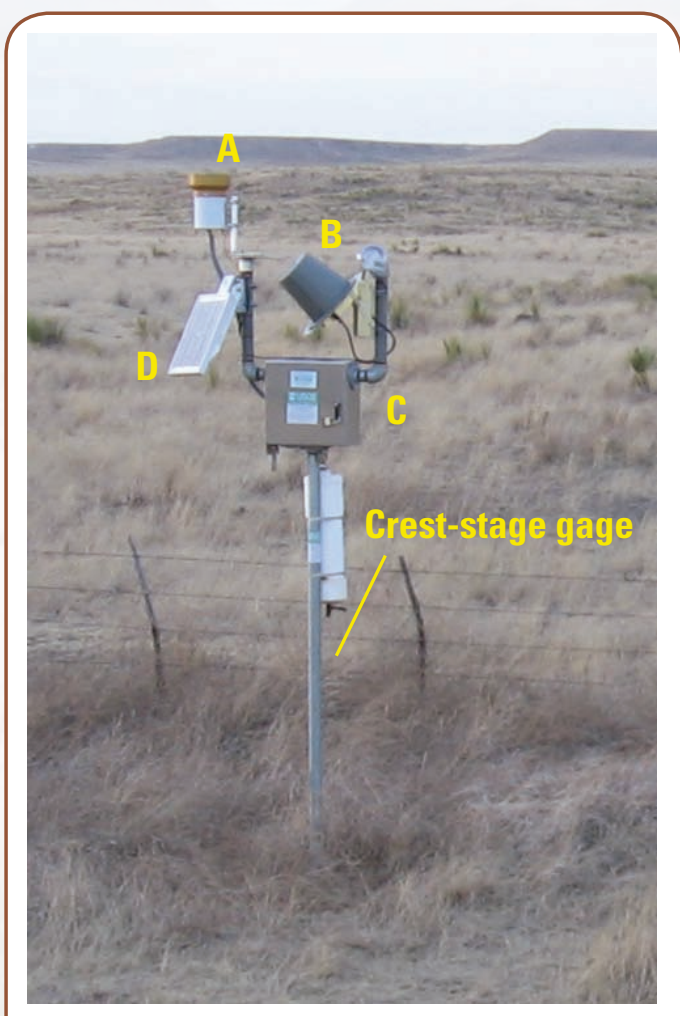

Figure 5. U.S. Geological Survey streamflowgaging station (station 07227460 , West Fork East Cheyenne Creek tributary near Channing, Texas) with some of the equipment used for real-time data collection: $A$, rain gage; $B$, antenna for satellite telemetry; $C$, equipment box with data logger; and D, solar panel.

Forty-seven of the 51 stations are located where roadways cross over culverts, and the hydraulics of these culverts are used to estimate discharge from the recorded headwater elevation near the upstream end of the culvert (upstream from culvert entrance) and tailwater elevation near the downstream end of the culvert (downstream from culvert exit) (Bodhaine, 1968; Davidian, 1984). For some stations, additional crest-stage gages are needed to adequately characterize the water-surface profile through the culverts and facilitate estimations of discharge under a wide range of flow conditions. The remaining four stations are located in stream reaches for which culvert hydraulics are not needed to estimate discharge; instead, the slope-area method with the slope-area computation (SAC) program is used. The SAC program is based on the procedures described by Dalrymple and Benson (1967).

Publishing support provided by

Lafayette and West Trenton Publishing Service Centers

\section{Selected References}

Asquith, W.H., and Slade, R.M., 1997, Regional equations for estimation of peak-streamflow frequency for natural basins in Texas: U.S. Geological Survey Water-Resources Investigations Report 96-4307, 68 p., available online at http://pubs.usgs.gov/wri/wri964307/.

Asquith, W.H., and Thompson, D.B., 2008, Alternative regression equations for estimation of annual peak-streamflow frequency for undeveloped watersheds in Texas using PRESS minimization: U.S. Geological Survey Scientific Investigations Report 2008-5084, 40 p., available online at http://pubs.usgs.gov/sir/2008/5084/.

Asquith, W.H., and Roussel, M.C., 2009, Regression equations for estimation of annual peak-streamflow frequency for undeveloped watersheds in Texas using an L-moment-based, PRESS-minimized, residual-adjusted approach: USGS Scientific Investigations Report 2009-5087, 48 p., available online at http://pubs.usgs.gov/sir/2009/5087/.

Bodhaine, G.L., 1968, Measurement of peak discharge at culverts by indirect methods: U.S. Geological Survey, Techniques of Water-Resources Investigations, book 3, chap. A3, 60 p., available online at http://pubs.usgs.gov/twri/twri3-a3/.

Carter, R.W., 1957, Computation of peak discharge at culverts: U.S. Geological Survey Circular 376, 25 p.

Dalrymple, Tate, and Benson, M.A., 1967, Measurement of peak discharge by the slope-area method: U.S. Geological Survey Techniques of Water-Resources Investigations, book 3, chap. A2, 12 p., available online at http://pubs.usgs. gov/twri/twri3-a2/.

Davidian, Jacob, 1984, Computation of water-surface profiles in open channels: U.S. Geological Survey Techniques of WaterResources Investigations, book 3, chap. A15, 48 p.

Fulford, J.M., 1998, User's guide to the U.S. Geological Survey Culvert Analysis Program, Version 97-08: U.S. Geological Survey Water-Resources Investigations Report 98-4166, $70 \mathrm{p}$.

Texas General Land Office, 1999, County boundaries: 1:24,000, available at http://www.glo.state.tx.us/gisdata/gisdata.html.

U.S. Geological Survey, 2011, National Water Information System, accessed March 2011 at http://waterdata.usgs.gov/tx/ nwis/.

—Glenn R. Harwell and William H. Asquith

For additional information, contact

Director, USGS Texas Water Science Center

http://tx.usgs.gov/

gs-w-txpublic-info@usgs.gov 